\title{
First report of stem wilt caused by Fusarium oxysporum f. sp. opuntiarum on Sulcorebutia rauschii in Italy
}

\author{
Angelo Garibaldi ${ }^{1} \cdot$ Domenico Bertetti $^{1}$ - Pietro Pensa ${ }^{1} \cdot$ Slavica Matić ${ }^{1} \cdot$ Maria Lodovica Gullino ${ }^{1}$
}

Received: 22 February 2019 / Accepted: 25 November 2019/Published online: 10 December 2019

(C) Società Italiana di Patologia Vegetale (S.I.Pa.V.) 2019

Keywords Ornamental plants $\cdot$ Cacti $\cdot$ Fusarium wilt

During June 2018, 50 2-year-old plants of Sulcorebutia rauschii G. Frank, Cactaceae family, growing in a nursery located in Ventimiglia (Imperia province, Northern Italy) wilted, collapsed and died. About 5\% of 1000 plants were symptomatic. From the affected collar and stem tissues, whitish to pale purple fungal colonies were isolated onto Potato Dextrose Agar (PDA), producing pale purple pigments in the medium. On Carnation Leaf Agar (CLA), colonies produced microconidia, macroconidia in sporodochia and chlamydospores. Unicellular, oval to elliptical microconidia were supported by short monophialides and measured $4.5-8.9 \times 1.7-$ $4.2 \mu \mathrm{m}$ (media: $6.5 \times 2.8 \mu \mathrm{m}$ ). Macroconidia were slightly falcate, septate with a foot-shaped basal cell and a short apical cell and measured 28.4-38.3 × 3.4-4.3 $\mu \mathrm{m}$ (average 34.1 $\times$ $3.8 \mu \mathrm{m})$. Smooth walled chlamydospores were terminal or intercalary, singles or in pairs (rarely in clumps) and measured 4.3-11.9 $\mu \mathrm{m}$ (average: $7.2 \mu \mathrm{m}$ ) in diam. These morphological features are typical of Fusarium oxysporum Schlechtendahl emend. Snyder \& Hansen (Leslie and Summerell 2006). The DNA was extracted by a pure culture of the isolate DB18GIU24 and the Intergenic Spacer Region (IGS) was amplified using primers CNS1/CNL12 and sequenced (GenBank accession No. MK482733). BLASTn analysis of the 936 bp segments showed $100 \%$ similarity with the sequence FJ985530 of F. oxysporum f. sp. opuntiarum W.L. Gordon. Pathogenicity of the isolate DB18GIU24 was tested on three healthy plants of $S$. rauschii by introducing sterile

Domenico Bertetti

domenico.bertetti@unito.it

1 Centre of Competence for the Innovation in the Agro-Environmental Sector (AGROINNOVA), University of Torino, Largo Paolo Braccini 2, 10095 Grugliasco, Torino, Italy needles contaminated with the inoculum into lesions ( 3 lesions/plant) produced on the stems (Talgø and Stensvand 2013). Three control plants were punctured with sterile needles without inoculum. Plants were maintained at temperatures ranging from 20 to $26{ }^{\circ} \mathrm{C}$. After 10 days, a slight depression of tissues around the needles appeared on inoculated plants. Internal tissues rotted and $F$. oxysporum f. sp. opuntiarum was reisolated. Controls remained symptomless. This is the first report of F. oxysporum f. sp. opuntiarum on $S$. rauschii in Italy, as well as worldwide (Farr and Rossman 2019). In Italy the production of S. rauschii is limited, however F. oxysporum f. sp. opuntiarum could spread on many succulent hosts (Gerlach 1972) that are widely grown.

\section{References}

Farr DF, Rossman AY (2019) Fungal Databases, U.S. National Fungus Collections, ARS, USDA. Retrieved May 21, 2019

Gerlach W (1972) Fusarium rot and other fungal diseases of horticulturally important cacti in Germany. Phytopathol Z 74:197-217

Leslie JF, Summerell BA (2006) The Fusarium laboratory manual. Blackwell, Ames

Talgø V, Stensvand A (2013) A simple and effective inoculation method for Phytophthora and fungal species on woody plants. OEPP/EPPO Bull 43(2):276-279

Publisher's note Springer Nature remains neutral with regard to jurisdictional claims in published maps and institutional affiliations. 